\title{
СХЕМА ВЕДЕНИЯ БЕРЕМЕННОСТИ ЖЕНЩИН С НЕДИФФЕРЕНЦИРОВАННОЙ ДИСПЛАЗИЕЙ СОЕДИНИТЕЛЬНОЙ ТКАНИ
}

\section{THE SCHEME OF MANAGEMENT OF PREGNANCY IN WOMEN WITH UNDIFFERENTIATED CONNECTIVE TISSUE DYSPLASIA}

T. Fadeeva

Summary. The syndrome of undifferentiated connective tissue dysplasia (NDST) is an urgent problem in obstetric practice. The syndrome can have a negative impact on the course of pregnancy and intrauterine fetal development delay, can cause premature outpouring of amniotic fluid, bleeding or birth abnormalities. This paper describes the algorithm of actions and management scheme for pregnant women with NDST. In the absence of visible manifestations of NDST or the presence of an entry in the medical record, the pregnant woman can be considered conditionally healthy, and further monitoring is carried out by a district obstetriciangynecologist. If a pregnant woman has a diagnosis of PDST before pregnancy, a risk assessment is calculated and drug therapy is prescribed. The standard scheme of pregnancy management applies to a physically healthy woman, whose medical history has no special pathologies or hereditary diseases. For any deviations from the norm, it is necessary to follow the algorithm of sequential actions, the purpose of which is to help carry out a healthy child and give birth to it on time.

Keywords: NDST, diagnosis of connective tissue dysplasia, pregnancy management scheme, medical and social support, therapy.

\section{Актуа^ьность}

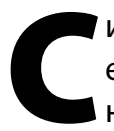

индром недифференцированной дисплазии соединительной ткани (НДСТ) является актуальной проблемой в акушерской практике. От 70\% до $80 \%$ женщин репродуктивного возраста страдают той или иной формой НДСТ, а у $50 \%$ женщин отмечается угроза прерывания беременности [1]. Данный синдром может оказывать неблагоприятное влияние на течение беременности, а также может спровоцировать преждевременные роды [2]. Среди внешних проявлений НДСТ широко распространены такие как [3]:

Астеническое телосложение - сужение всех конечностей, включая грудную клетку, продолговатая форма лица, непропорциональная длина рук.

\author{
Фадеева Татьяна Сергеевна \\ Врач акушер-гинеколог, г. Калуга \\ fdv_tana@mail.ru
}

Аннотация. Синдром недифференцированной дисплазии соединительной ткани (НДСТ) является актуальной проблемой в акушерской практике. Синдром может оказывать негативное влияние на течение беременности и внутриутробную задержку развития плода, может вызвать преждевременное излитие околоплодных вод, кровотечение или аномалии родовой деятельности. В данной работе описывается алгоритм действий и схема ведения беременных женщин с НДСТ. При отсутствии видимых проявлений НДСТ или наличия записи в медицинской карте, беременная может считаться условно здоровой, а дальнейшее наблюдение осуществляется участковым акушером-гинекологом. При наличии у беременной женщины диагноза НДСТ до беременности, проводится расчет оценки риска и назначается терапия препаратами. Стандартная схема ведения беременности распространяется на физически здоровую женщину, в истории болезни которой нет особых патологий и наследственных заболеваний. При любых отклонениях от нормы необходимо следовать алгоритму последовательных действий, цель которых — помочь выносит здорового ребенка и родить его в срок.

Ключевые слова: НДСТ, диагностика дисплазии соединительной ткани, схема ведения беременности, медико-социальная поддержка, терапия.

Аномалия прикуса:

- дистальный прикус (недоразвитость нижней челюсти);

- мезиальный прикус (противоположен дистальному прикусу);

- открытый прикус (часть зубов не смыкаются и образуют щель);

- глубокий прикус (резцы верхнего ряда перекрывают резцы нижнего ряда);

- перекрестный прикус (слабо развита какая-либо сторона любой челюсти);

- дистопия (зубы располагаются не на своем месте в зубном ряду);

- диастема (наличие щели между центральными резцами верхней челюсти, намного реже нижней челюсти). 
Искривленные мизиниыь - пальцы скошены медиально или латерально, что является частным проявлением такого заболевания как клинодактилия.

Сколиоз - искривления позвоночника, чаще всего встречаются незначительные искривления позвоночника грудного отдела.

Плоскостопие - изменение формы стопы, характеризующееся опущением её продольного и поперечного сводов.

\section{Миопия- близорукость.}

Еще одним признаком данного заболевания является бледность кожи.

К числу висцеральных фенотипических маркеров относят аномалии сердечно-сосудистой системы, такие как: гипоплазия левого сердца (недоразвитость сердца с левой стороны, которая может привести к летальному исходу); транспозиция магистральных сосудов (дискордантное желудочково-артериальное соединение) и т.д. [4], [5]. А также аномалии мочевой системы, например: поражение почек (органы, очищающие кровь и образующие мочу); мочеточников (каналы, ведущие от почек до мочевого пузыря); мочевого пузыря (орган, в котором содержится моча); уретры (канал, через который моча высвобождается из мочевого пузыря) [6]. НДСТ также имеет важное значение в развитии варикозной болезни нижних конечностей [7].

Согласно исследованию, проведенному Лукиной Т.С. [8], чаще всего у женщин с НДСТ встречаются стигмы дизэмбриогенеза, небольшие внешние фенотипические проявления НДСТ. Они есть у каждого человека, но при отсутствии НДСТ число данных отклонений не должно превышать пяти.

Кроме того, проводятся антропометрические исследования, которые основываются на измерении длины верхних конечностей (расстояние между выступающей точкой на крае акромиального отростка лопатки и дистальной точкой ногтевой фаланги 3-го пальца), длине плеча (расстояние от выступающей точки на крае акромиального отростка лопатки до верхней точки головки лучевой кости), длине предплечья (расстояние от нижней точки шиловидного отростка лучевой кости до верхней точки головки лучевой кости), длине кисти (расстояние между проекцией шиловидной кости на продолжение линии третьей пястной кости до самой дистальной точки ногтевой фаланги 3-го пальца), длине нижней конечности (расстояние от большого вертела до пола), длине бедра (расстояние между верхним краем лонного сочленения и сере- диной медиального мыщелка большеберцовой кости), длине голени (расстояние между серединой медиального мыщелка большеберцовой кости и нижней точкой на внутренней лодыжке), длине стопы (расстояние от пяточного бугра до конца ногтевой фаланги 2-го пальца) [9].

\section{Шель исслеАования}

Любое ведение беременности акушером-гинекологом, подчинено определенному алгоритму последовательных действий. В данной работе описывается схема ведения беременных женщин с НДСТ.

\section{Материалы и метолы исслеАования}

Схематически ведение беременности женщин с НДСТ условно можно разделить на два основных направления:

1. Ведение беременности условно здоровой женщины;

2. Ведение беременности женщины, которая знала, что она больна дисплазией соединительной ткани (ДСТ) до беременности.

Каждый из данных направлений включает в себя необходимый алгоритм действий. Рассмотрим каждое из данных направлений.

\section{Результаты}

Алгоритм действий медико-социальной поддержки и ведения беременных женщин с НДСТ представлен схематически на Рисунке 1.

\section{Ведение беременности условно зАОровой женшины}

При отсутствии видимых симптомов НДСТ или записи о наличии НДСТ в медицинской карте, беременная может считаться условно здоровой женщиной. В данном случае назначается консультация и осмотр у врача терапевта, чтобы определить наличие или отсутствие фенотипических маркеров НДСТ (Рисунок 1). В ходе данной консультации терапевт устанавливает наличие или отсутствие у женщин признаков НДСТ.

Если у женщины обнаружены фенотипические признаки НДСТ и есть астенические жалобы, то необходимо проведение специальных приемов по прерыванию беременности, которые проводятся хотя бы до 12 недель. Если же у женщины отсутствуют фенотипические признаки НДСТ и есть астенические жалобы, то дальнейшее наблюдение осуществляется участковым акушером-гинекологом. 
Беременность

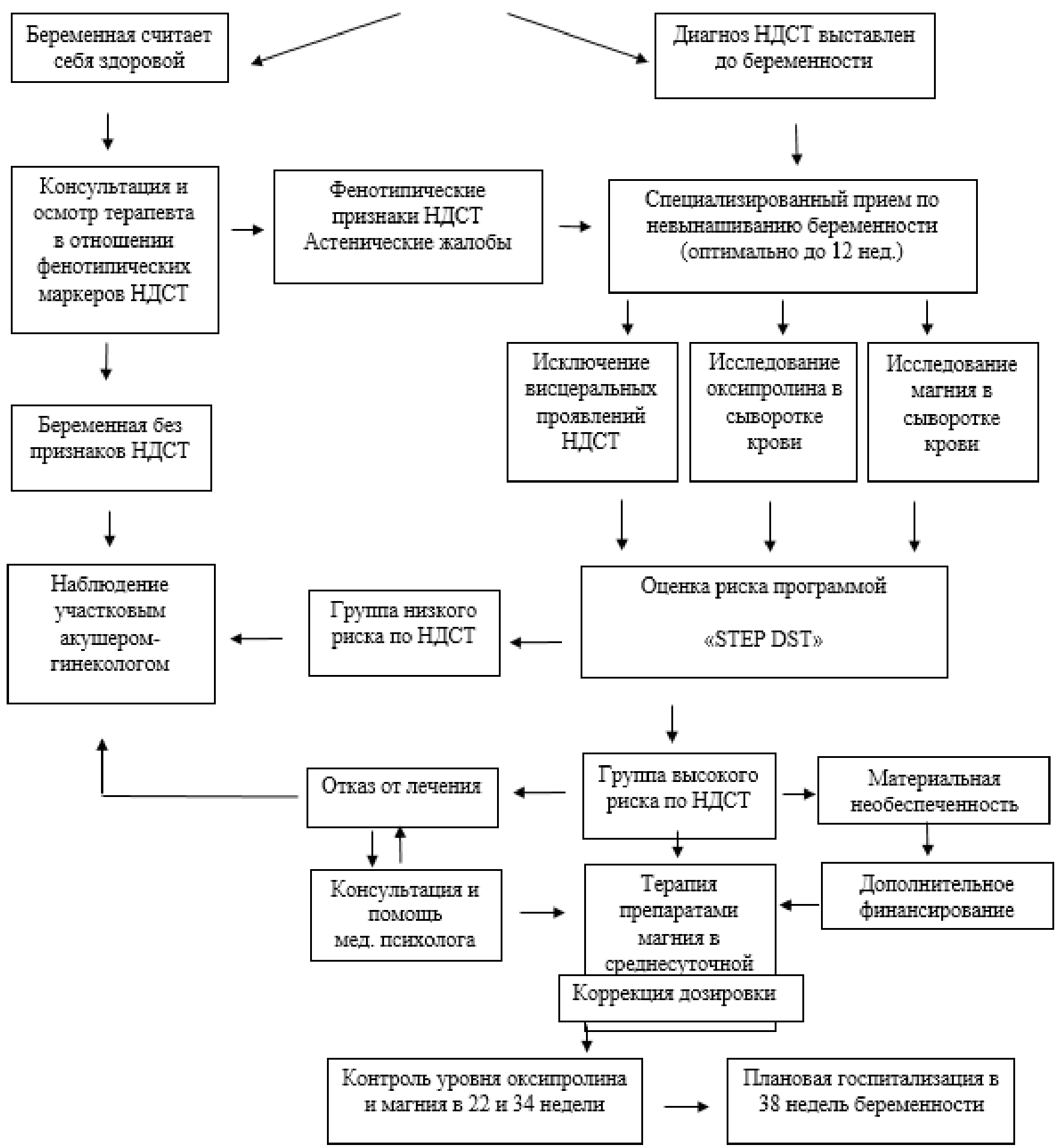

Рис. 1. Схема медико-социальной поддержки и ведения беременных женщин с НДСТ. 
Ведение женшины

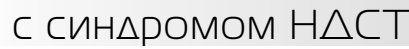

Многие женщины, находясь еще в юношеском возрасте, узнают о наличии НДСТ, что фиксируется в их медицинских картах. При наличии у беременной женщины диагноза НДСТ, в первую очередь, необходимо проведение специализированного обследования, который проводится до 12 недель. В ходе данного приема производятся исследования висцеральных проявлений НДСТ, оксипролина и магния в сыворотке крови. После, проводится расчет оценки риска, который основывается на данных программы «StepDST» [10].

Беременных женщин с НДСТ можно разделить на две группы риска:

- Группу низкого риска: когда фенотипические признаки НДСТ в меньшей степени влияют на ход беременности и родов. Данная группа, как и женщины, у которых отсутствует диагноз НДСТ, в дальнейшем наблюдаются участковым акушером-гинекологом.

- Групnу высокого риска: когда фенотипические признаки НДСТ могут привести к осложнениям беременности и родов. Именно женщины данной группы нуждаются в проведении магниевой терапии.

В случае, если женщина, относящаяся к группе высокого риска не отказывается от проведения терапии препаратами магния, то контроль магния и оксипролина осуществляется в 22 и 34 недели. Госпитализация женщин группы высокого риска планируется на 38 неделе беременности, если нет серьезных оснований для госпитализации раньше. Однако, женщина может отказаться от данного лечения и наблюдаться у участкового акушера-гинеколога, при этом осуществляется консультация и помощь медицинского психолога.

\section{Тактика ведения беременности

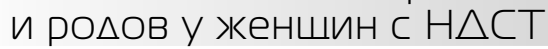

В данной части работы описывается ведения беременных группы высокого риска, у которых возможны осложнения беременности и родов.

Проанализируем принципы ведения пациенток группы высокого риска по развитию плацентарных нарушений и гестоза. На ранней стадии необходима диагностика, затем проводятся доклиническая профилактика осложнений в критические сроки гестации, связанные с первой и второй волной инвазии трофобласта и обоснованное по срокам и составу комплексное лечение.
На доклиническом этапе обследования образуются группы беременных в зависимости от наличия или возможности формирования той или иной патологии. Данные группы различаются по срокам беременности:

- для первой половины срока - гестации - это группы риска по раннему токсикозу и угрозе прерывания;

- для второй половины указанного срока - это плацентарные нарушения и гестоз, внутриутробная гипоксия и внутриутробная задержка развития плода, преждевременное излитие околоплодных вод, кровотечение и аномалии родовой деятельности.

Необходимо отметить, что не все пациентки с НДСТ группы высокого риска обладают достаточным финансированием для проведения терапии магниевыми препаратами. Женщинам данной группы выделяется дополнительное финансирование, которое осуществляется государством, что предполагает наличие бесплатных услуг и препаратов для беременных.

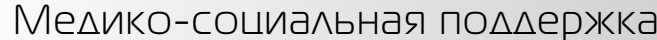 беременных женшин с $H \triangle С Т$}

Существует конкретный перечень услуг и препаратов, которые беременная женщина может получить бесплатно в качестве дополнительного финансирования, что фиксируется в следующих нормативно-правовых актах:

1. Письмо от 16 июля 2007 г. N15-4/1360-09 об оказании платных услуг во время беременности и родов (с изм., внесенными письмом Минздравсоцразвития РФ от 13.11.2007 N15-4/2187-09). Согласно которому «оказание платных медицинских услуг не может осуществляться в ущерб гарантированному объему бесплатной медицинской помощи».

2. Приказ от 14 сентября 2006 г. N662 об утверждении стандарта медицинской помощи женщинам с нормальным течением беременности, в нем фиксируется перечень необходимых медицинских обследований как непосредственно специалистами, так и требующие специализированного оборудования (анализы, УЗИ и прочее).

3. Письмо от 13 ноября 2007 г. N15-4/2187-09 определяет общие положения платного обслуживания беременных женщин, то есть то, что не выходит за рамки дополнительного финансирования государством.

4. Приказ от 19 января 2007 г. N50 «О порядке и условиях расходования средств, связанных с оплатой государственным и муниципальным учреждениям здравоохранения услуг по медицинской помощи, оказанной женщинам в период беремен- 
Таблица 1. Перечень бесплатных услуг по ОМС.

\begin{tabular}{|c|c|c|}
\hline Наименование & Частота предоставления & Среднее количество \\
\hline Сбор анамнеза и жалоб в гинекологии & 1 & 15 \\
\hline Визуальное исследование в гинекологии & 1 & 12 \\
\hline Пальпация в гинекологии & 1 & 12 \\
\hline Исследование пульса & 1 & 12 \\
\hline Измерение артериального давления на периферических артериях & 1 & 12 \\
\hline Измерение размеров матки & 1 & 8 \\
\hline Аускультация плода с помощью стетоскопа & 1 & 8 \\
\hline Пальпация плода & 1 & 8 \\
\hline Измерение массы тела & 1 & 12 \\
\hline Осмотр шейки матки в зеркалах & 1 & 1 \\
\hline Получение цервикального мазка & 1 & 2 \\
\hline Получение влагалищного мазка & 1 & 3 \\
\hline Ультразвуковое исследование плода & 1 & 2 \\
\hline Кардиотокография плода & 1 & 2 \\
\hline Подготовка беременных к родам & 1 & 3 \\
\hline Обучение уходу за новорожденным & 1 & 3 \\
\hline Психологическая адаптация & 1 & 3 \\
\hline Аутогенная тренировка & 1 & 3 \\
\hline Пособие по наложению бандажа при беременности & 1 & 1 \\
\hline Назначение лекарственной терапии при беременности & 1 & 12 \\
\hline Назначение диетической терапии при беременности & 1 & 12 \\
\hline Назначение лечебно-оздоровительного режима при беременности & 1 & 12 \\
\hline Взятие крови из пальца & 1 & 3 \\
\hline Взятие крови из периферической вены & 1 & 2 \\
\hline Исследование уровня лейкоцитов в крови & 1 & 3 \\
\hline
\end{tabular}

ности, в период родов и послеродовой период, а также по диспансерному наблюдению ребенка в течение первого года жизни».

Отметим, что для того, чтобы использовать дополнительное финансирование, необходимо наличие полиса обязательного медицинского страхования (ОМС), который действует лишь в государственных органах здравоохранения. В Таблице 1 представлен частичный перечень бесплатных услуг, которые полис ОМС позволяет получить беременной женщине.

К списку препаратов, которые могут предоставляться бесплатно относят: фолиевую кислоту, витамин Е, кальция карбонат и т.д. Однако, данный перечень каждый год может изменяться Министерством Здравоохранения.

\section{Выво $\triangle \mathrm{b}$}

Значение состояния гемостаза является одним из наиболее частых осложнений для развития плода и исхода родов. В связи с этим, у беременных с НДСТ помимо указанной схемы ведения беременности, необходимо применять алгоритм клинико-гемостазиологических исследований. Один из последних таких алгоритмов был предложен П.А. Кирющенковым и соавторами [11], в котором они обобщают существующие анамнестические данные, анализ клинической ситуации с выполнением общих оценочных и отдельных специальных гемостазиологических тестов, установление диагноза и подбор необходимой терапии.

При наличии любой патологии у беременной женщины с НДСТ в первом триместре рекомендуется специальная диета, которая характеризуется повышенным содержанием белков и гликозаминогликанов, которые позволяют регулировать тонус и моторику желудочно-кишечного тракта, а также витамин Е (400 ME в сутки). При назначении тех или иных препаратов необходимо учитывать, что препараты, понижающие коагуляционный потенциал, могут привести к снижению геморрагических проявлений у женщин с синдромом мезенхи- 
мальной дисплазии. Кроме того, необходимо помнить, что ДСТ в большинстве случаев характеризуется облигатным магниево-дефицитным состоянием [11].

Согласно данным исследования В.Е.Радзинского [12], профилактическое назначения магния является важной и обязательной частью этиопатогенетической терапии, что позволяет своевременно купировать тонус матки и является одним из основных способов профилактики задержки внутриутробного роста плода. В работе Л.Б. Лазебник и соавторов [13], описана взаимосвязь концентрации магния в крови с развитием геморрагического синдрома на фоне НДСТ. Геморрагический синдром у беременных с диагнозом НДСТ характеризуется ангиопатичностью, влияющей на снижении плотности сосудистой стенки, обусловленной деградацией коллагеновых и эластических волокон, а также полисахаридных гиалуроновых нитей.

Лечение беременных с диагнозом НДСТ проводится посредствам назначения таблетированных препаратов магния, что фиксируется в общей схеме ведения беременных женщин с НДСТ. Такое лечение считается оправданным с позиции рациональной фармакотерапии беременных. Кроме того, данное лечение может проводится без лабораторного подтверждения магниевого дефицита в связи с его малой информативностью [14].

Для профилактики и коррекции гиперкоагуляционных нарушений в системе гемостаза у беременных женщин группы высокого риска, в связи с развитием тромботических осложнений, применяются низкомолекулярные гепарины (НМГ), которые иногда даже называют «золо- тым стандартом» профилактической антикоагулянтной терапии. Однако, к назначению препаратов этой группы надо подходить осторожно, учитывая тромбогеморрагический характер проявлений нарушений гемостаза у пациентов с НДСТ. Для пациентов этой группы оптимально использовать методы неспецифической профилактики (эластическая компрессия нижних конечностей, диета и т.д.), а также назначение флеботоников. Флеботоники, являются важным компонентом алгоритма ведения беременных с НДСТ, в ситуации, когда у последних обнаруживаются явления хронической венозной недостаточности. Диосмин (Diosmin) является одним из популярных флеботоников, способных оказывать нормализующее влияние на состояние системы гемостаза.

При наличии развития акушерских кровотечений, основные методы лечения должны являются средства местного и общего действия. Для остановки кровотечения чаще всего используются хирургические методы, гемостатическая губка, а также препараты антифибринолитического действия (транексамовая кислота). По общепринятым показаниям - инфузионно-трансфузионная терапия. При массивных кровопотерях оправдано применение препарата рекомбинантного активированного фактора свертывания крови.

Стандартная схема ведения беременности распространяется на физически здоровую женщину, в истории болезни которой нет наследственных заболеваний и особых патологий. При любых отклонениях от нормы необходимо следовать определенному алгоритму последовательных действий, цель которых - помочь выносить здорового ребенка и родить его в срок.

\section{ЛИТЕРАТУРА}

1. Смирнова Т.Л., Герасимова Л. И., Сидоров А. Е., Чернышов В. В., Губанова Е. А. Особенности течения беременности и родов у женщин с синдромом недифференцированной дисплазии соединительной ткани // Клиническая медицина. 2018. № 6. С. 39-44.

2. Керимкулова Н.В., Никифорова Н. В., Владимирова И. С., Торшин И. Ю., Громова О. А. Влияние недифференцированной дисплазии соединительной ткани на исходы беременности и родов. комплексное обследование беременных с дисплазией соединительной ткани с использованием методов интеллектуального анализа данных // Земский врач. 2013. № 2 (19). С. 34-38.

3. Нечаева Г.И., Яковлев В. М., Конев В. П., Друк И. В., Морозов С. Л. Дисплазия соединительной ткани: основные клинические синдромы, формулировка диагноза, лечение // Лечащий врач. 2008. № 2. С. 22-28.

4. Биндус 0. В. Врожденные пороки сердца как проявление дисплазии соединительной ткани // Смоленский медицинский альманах. 2015. № 1. С. 8-9.

5. Гусева Е. С. Дисплазия соединительной ткани у беременных: особенности клинического течения и прогнозирование экстрасистолии высоких градаций // Автореф. дис. канд. мед. наук. 2014.

6. Нечаева Г.И., Логинова Е. Н., Цуканов А. Ю., Семенкин А. А., Фисун Н. И., Дрокина О. В. Патология почек при дисплазии соединительной ткани: междисциплинарный подход // Лечащий врач. 2016. № 1. С. 54-57.

7. Потапов М.П., Потапов П.П., Ставер Е. В., Мазепина Л. С. Неспецифическая дисплазия соединительной ткани в развитии первичного варикозного расширения вен нижних конечностей // Пульс. 2016. № 8. С. 54-58.

8. Лукина Т. С. Оптимизация математического моделирования и прогнозирования анализа течения беременности и родов у женщин с недифференциальной дисплазией соединительной ткани // Автореф.дисс.канд.мед.наук. 2003. С. 57-58.

9. Васильев 0.С., Левушкин С. П. Сравнительный анализ антропометрических параметров как фенотипических маркеров синдрома дисплазии соединительной ткани у спортсменов // Медицина экстремальных ситуаций. 2015. С. 75-79. 
10. Лукина Т. С. Математическое моделирование и прогнозирование дисплазии соединительной ткани путем создания программы “StерDST” // 06разование и наука в современных условиях. 2015. № 3. С. 38-39.

11. Кирющенков П.А., Шмаков Р.Г., Андамова Е. В., Тамбовцева М. А. Алгоритм клинико-гемостазиологического обследования в акушерско-гинекологической практике // Акушерство и гинекология. 2013. № 1. С. 101-106.

12. Радзинский В.Е., Ордиянц И. М. Альтернативные подходы к анемии беременных // Акушерство и гинекология. 2007. № 3. С. 65-67.

13. Лазебник Л.Б., Михеева О. М., Щербаков П. Л., Ефремов Л. И., Кирова М. В. Ангиодисплазии и геморрагии желудочно-кишечного тракта как частное проявление дисплазии соединительной ткани // Экспериментальная и клиническая гастроэнтерология. 2010. № 4. С. 114-120.

14. Кудинова Е. Г. Генетические тромбофилии у девушек смезенхимальными дисплазиями // Сибирский медицинский журнал. 2011. № 3. С. 97-99.

○ Фадеева Татьяна Сергеевна ( fdv_tana@mail.ru ).

Журнал «Современная наука: актуальные проблемы теории и практики» 